\title{
Likelihood of propensity to travel: Prediction based on socio-demographic factors
}

\author{
Sejfudin Zahirović ${ }^{1}$, Jas mina Okičić ${ }^{1 *}$, Mensur Herić ${ }^{1}$, Dino Kakeš ${ }^{2}$ \\ ${ }^{1}$ University of Tuzla, Faculty of Economics, Tuzla, Bosnia and Herzegovina \\ ${ }^{2}$ Indirect Taxation Authority of Bosnia and Herzegovina, Bosnia and Herzegovina
}

\begin{abstract}
The purpose of this research is to provide some insights into socio-demographic determinants of predicting the likelihood of residents propensity to travel. Using the quota sampling technique, data collection was carried out from October to December 2019, yielding a sample of 632 valid responses. To gain a better understanding of the sociodemographic determinants of propensity to travel, we, primarily, use descriptive statistical analys is, chi-square test and probit regression model. The research findings have revealed that age, education and household income characteristics may be considered as antecedents of travel propensity of residents. Having in mind the impact that Covid-19 pandemic has on sector of touris mworldwide, and based on the results of this research, policymakers' efforts should be directed to promoting local touris testinations and to enhancing tourism literacy of residents.
\end{abstract}

Keywords: propensity to travel, prediction, likelihood, socio-demographic determinants JEL classification: C83, L83, C25

\section{Verovatnoća sklonosti putovanju: Predikcija bazirana na socio-demografskim faktorima}

Sažetak: Cilj ovog is traživanja je da pruži uvid u socio-demografske determinante predikcije verovatnoće sklonosti turis tičkom putovanju rezidenata. Koristeći kvota uzorak od 632 is pitanika, prikupljanje podataka vršenoje od oktobra do decembra meseca2019. godine. Da bi se steklo bolje razumevanje socio-demografskih determinanti sklonosti turističkom putovanju, korišćene su deskriptivna statis tička analiza, hi-kvadrat test i probit regresioni model. Nalazi is traživanja otkrili su da se starost, obrazo vanje i prihod domaćinstva mogu smatrati prediktorima njihove sklonosti turističkom putovanju. Imajući u vidu uticaj koji pandemija Covid-19 ima na turistički sektor širom sveta, a na osnovu rezultata ovog istraživanja, napori kreatora politika trebalo bi da budu usmereni na promociju lokalnih turis tičkih destinacija i na unapređenje turis tičke pismenosti rezidenata.

Ključne reči: sklonost turističkomputovanju, predikcija, verovatnoća, socio-demografske determinante

JEL klasifikacija: C83, L83, C25

*jasmina.okicic@untz.ba

This article is an open access article distributed under the terms and conditions of the Creative Commons Attribution (CC BY) license (http://creativecommons.org/licenses/by/4.0/). 


\section{Introduction}

As pointed out by Kožić et al. (2016) propensity to travel is profoundly entrenched into the core of tourismdemand. Extensive and important research of propensity to travel has already been conducted. As key factors of travel propensity socio-demographic factors are recognized (Ching-Fu \& Wu, 2009; Handayani \& Djamaluddin, 2016; Seyidov \& Adomaitiené, 2016; Thrane et al., 2016; Toivonen, 2004). Besides, the impact of psychological factors on travel propensity is found in Dogru (2016) and Letheren et al. (2017). In addition, the characteristics of tourist product, such as destination, voyage, and event, as impacting factors regarding travel propensity are recognized in Bianchi and Milberg (2017), Choi et al. (2019), Gurbaskan Akyuz (2019) and Hur and Adler (2013). However, not many of thesestudies concentrate on the perspective of residents and their propensity to visit tourist destinations. The studies of propensity to travel enable identification of subjective and objective factors that have stimulating role in tourist market and services development. One of the tourist marketing goals could be discovering, stimulating, and creating permanent propensity to travel. The knowledge about domicile population (residents') propensity to travel can represent u seful base for the improvement of domes tic and international tourist supply, development of new touris mproducts and business models, the creation of a specific promotional mix, etc.

In that respect, theauthors selected the subject of this paper on the ground that not many relevant publications with a focus on the propensity to travel of residents in countries dealing with the transitionaleconomy, such as Bosnia and Herzegovina $(\mathrm{B} \& \mathrm{H})$, can be found in the contemporary literature.

Therefore, based on the above-identified research gap, the purpose of this research is to provide some insights into socio-demographic determinants of the residents' propensity to travel.

Key research objectives are as follows:

RO1. To determine statis tically significant difference between the propensity to travel and selected socio-demographic factors.

RO2. To explain the impact of the selected socio-demographic factors on the likelihood of the propensity to travel.

The paper is organized as follows. After the introduction, a brief overview of a theoretical context that is applicable to the research is provided. The paper goes on to explain the methodology, after which the findings are discussed. Ultimately, in line with the results of the study, a brief description of the key conclusions is given.

\section{Lite rature review and hypothesis development}

There are numerous studies identifying the relationship between socio-demographic factors and propensity to travel. The research conducted by Seyidov and Adomaitiene (2016) encompassed individuals in Azerbaijan as they behave in connection with making decisions related to native tourism. It has been shown that the len gth of journey, as special as pect of tourist behavior, is influenced by age group. Besides, revenue per month and matrimonial status of native travelers, similarly, have an effect on their way of behaving. In the study carried out by Toivonen (2004), the author explored dis tinctions among countries in relation to propensity to travel to foreign countries on holiday. The author found out that the propensity is not directly affected by age and gender. However, age and regime, in interaction, haveclear-cuteffect on the propensity. In connection to changes, in countries 
with low level of propensity, age groups that encompass younger individuals, have exhibited the growth of propensity to travel that surpass expectations. Ching-Fu and Wu (2009) empirically explored propensity of the elder in Taiwan to travel overseas respecting the influences of socio-demographic factors. Beside these factors, their study also included the effects of travelling motives and leisure constraints. Regarding motives, they identified: amusement, novelty, getaway, and socialization. Related to the constraints, they noted perceived risk, dedication of time, and individual causes. Using binary logis tic regression, they demonstrated that, on the motive side, the major factors of propensity to travel are relaxation, socialization, and novelty. Furthermore, on the side of constraints, as major factor, individual reasons are observed. Finally, from the socio-demographic group of factors, the stage of life, source of revenue, and status of employment have been found to be important factors. According to Kožić et al. (2016), propensity to travel, in the sense of broad definition, can be viewed as inclination of an individual to be a tourist. As such, travelling propensity can be regarded as one of the most es sential concepts of investigating touris $m$. Macro-aspectexamination of the factors that shape propensity to travel, conducted by the authors, highlights income as the most influential factor. In the context of Indonesia, Handayani and Djamaluddin (2016) analyzed propensity of Indonesian families to go on vacation. Their results showed that income positively affects the probability of a household to have a holiday. Similar can be said for the years of education. Regarding gender, they found that households headed by man have lower probability to go on vacation th an households headed by women. Besides, they found that age has a positive effect on the probability to go on vacation, but these results were not significant. Another study differentiates between package tours and individual travel. Using micro data, Thrane et al. (2016) explored the propensity of tourists to select package vacation over an independent trip. Related to this kind of propensity, socio-demographic variables played a minor role. At the same time, variables related to journey and residence in sense of country came up as principal factors. This study results demonstrate, in respect to selection propensity, that ag ing increases propensity for package tours. Similar is true for situation when someone is first time visitor.

Besides socio-demographic factors, psychological factors of respondents have the role in shaping travel propensity. In his study Dogru (2016) analyzed financial behavior and economic confidence as factors that affect propensity of Chinese households to purchase vacation packages. The study results showed that households' financial behavior factors and subjective economic confidence affect propensity to buy a vacation package. Letheren et al. (2017) conducted a study in Australian context examining interplay between anthropomorphic inclination and personification of commercials and how that interplay affects feelings toward destination and intention to take a trip. The study results demonstrated the existence of a mechanism which functions in a way based on anthropomorphic inclination. Individuals characterized by high degree of anthropomorphic inclination demonstrate feelings colored with increased positivism in case personalized commercials are directed to them. This finding is a chance for achieving better tourism results.

The characteris tics of a touris mproduct, such as destination, voyage, and event, have been discussed in variou s research papers. Propensity as willingness to experience tourism supply is addressed in Hur and Adler (2013), who, using survey data, explored degree of knowledge, willingness and desired travel models of Koreans in connection with travelling by cruise ships. The large part of subjects who had not travelled by a cruise ship before expressed readiness to do that if they had a chance hereafter. The preferred duration of this kind of travel was one-week cruise, with preferred destinations being Mediterranean and Northern Europe. Hence, we can say that authors examine the propensity of subjects to take 
travel by a cruise ship. In that sense, the authors single out some elements that are most influential regarding decision to go on a cruise. Those elements are: total cost, cruise itinerary, cruise ship voyage length, capacities of cruise ship and comforts, activities of gaming, etc. The role of food in travel intentions is examined in Gurbaskan Akyuz (2019) who explored intentions to travel in relation to local food consumption. The study lis ts some food-related factors that can be used as predictors of intentions to travel, such as openness to gain food experience, participation of food in touris m supply, and fear of new food. The study demonstrated that participation of food and motivation to take a trip are connected to the intention to travel by individuals. Individuals with strong positive food image exhibited that food image plays moderating role in the connection between fear of new food and motivation to take a trip. Relationship between risk and tourist activity is important. Regarding that Choi et al. (2019) examined perceptions of risk of prospective tourists and their travel intentions to a country that is a host of big sports competition. The study results suggest that there is a difference in relation to negative impacts between terroris $m$ ris $k$ and political uncertainty on intentions to take a trip. The authors demonstrate that intention to take a trip is negatively affected by a terrorism risk. At the same time, political uncertainty does not show that sort of effect. According to these results, a terrorism risk is a sensitive is sue for a country that is the host of s ports competition. In their article, Bianchi and Milberg (2017) examined influencing factors regarding intention of individuals to travel to long distance destination for vacation purposes. The addressed context was where the individuals have not stay in that long distance place before. In case of travelers from Chile and their intention to stay in Australia for the purpose of vacation, the authors found that the image of the destination has an important role to play. Similar can be said for the value of the destination. Furthermore, the fact that individuals are aware of Australia affect indirectly their intention to visit that destination through the image of a brand. Interestingly, the authors found that the quality of brand perceptions was not important for intention of travelers from Chile to stay, for reasons of taking a vacation, in Australia.

Based on the previously mentioned literature, the most important socio-demographic factors of travel propensity are presented in Table 1 .

Table 1: Main socio-demographic factors of propensity to travel

\begin{tabular}{|c|l|}
\hline Factor & \multicolumn{1}{|c|}{ Source } \\
\hline Age & $\begin{array}{l}\text { Ching-Fu \& Wu (2009), Handayani \& Djamaluddin (2016), Seyidov \& } \\
\text { Adomaitienė (2016), Thrane et al. (2016), Toivonen (2004) }\end{array}$ \\
\hline Gender & Handayani \& Djamaluddin (2016), Toivonen (2004) \\
\hline Education & Handayani \& Djamaluddin (2016) \\
\hline Income & $\begin{array}{l}\text { Ching-Fu \& Wu (2009), Handayani \& Djamaluddin (2016), Kožić et al. } \\
\text { (2016), Seyidov \& Adomaitiene (2016) }\end{array}$ \\
\hline
\end{tabular}

Source: Author's research

In this paper, propensity to travel represents an individual's affinity orimpulse of a person to visit and stay in different destinations domes tically and abroad. It originates from influences of multiple subjective and objective factors.

Based on the previous discussion, we propose the following hypothes is:

H: Socio-demographic characteristics may be considered as antecedents of travelpropensity. 


\section{Mate rials and methods}

\subsection{Data source and sample}

Using the purposive sampling technique, data collection was carried out from October to December 2019, yielding a sample of 632 valid respondents. Table 2 provides a short overview of the sample's basic features.

Table 2: Sample description

\begin{tabular}{|c|c|c|}
\hline Characteristic & Frequency & $\%$ \\
\hline \multicolumn{3}{|l|}{ Respondent's sex } \\
\hline Male & 322 & 50.95 \\
\hline Female & 310 & 49.05 \\
\hline Total & 632 & 100.00 \\
\hline \multicolumn{3}{|l|}{ Residence } \\
\hline Urban & 299 & 47.30 \\
\hline Rural & 333 & 52.70 \\
\hline Total & 632 & 100.00 \\
\hline \multicolumn{3}{|l|}{ Age category } \\
\hline Age category: $<25$ & 229 & 36.23 \\
\hline Age category: $26-35$ & 186 & 29.43 \\
\hline Age category: $36-45$ & 99 & 15.67 \\
\hline Age category: $46-55$ & 68 & 10.76 \\
\hline Age category: $>55$ & 50 & 7.91 \\
\hline Total & 632 & 100.00 \\
\hline \multicolumn{3}{|l|}{ Current marital status } \\
\hline Unmarried/single & 314 & 49.68 \\
\hline Married & 260 & 41.14 \\
\hline Widowed/Widower & 33 & 5.22 \\
\hline Divorced/Separated & 25 & 3.96 \\
\hline Total & 632 & 100.00 \\
\hline \multicolumn{3}{|l|}{ Education } \\
\hline Elementary education & 52 & 8.23 \\
\hline Completed secondary school & 351 & 55.54 \\
\hline University I cycle & 206 & 32.59 \\
\hline University II or III cycle & 23 & 3.64 \\
\hline Total & 632 & 100.00 \\
\hline \multicolumn{3}{|l|}{ Household income } \\
\hline$<500 \mathrm{BAM}$ & 90 & 14.24 \\
\hline 501-1,000 BAM & 187 & 29.59 \\
\hline $1,001-1,500$ BAM & 175 & 27.69 \\
\hline $1,501-2,000$ BAM & 112 & 17.72 \\
\hline$>2,000 \mathrm{BAM}$ & 68 & 10.76 \\
\hline Total & 632 & 100.00 \\
\hline
\end{tabular}

Source: Author's research

The data collection ins trument is a structured questionnaire with clos ed questions, divided into several sections. 
The first section addresses the satisfaction with the tourist offer, whereas the second section considers specific socio-economic characteristics of the respondents.

\subsection{Research variables and methods}

Besides socio-demographic variables, presented in Table 2, the following variables were also used:

- propensity to visit tourist destinations in $B \& H$, as a binary dependent variable $(\mathrm{D}=$ 1 if the respondent has visited at least one touristic destination in $\mathrm{B} \& \mathrm{H}, 0$ otherwise).

- $\quad$ propensity to travel abroad, as a binary dependent variable $(D=1$ if the respondent has visited at least one touristic destination outside $\mathrm{B} \& \mathrm{H}, 0$ otherwise).

As Kožić et al. (2016) have already stated, age, education and income are three theoretically most debated socio-demographic determinants of the propensity to travel.

In that respect, and to get a clearer understanding of the factors that may influence the likelihood of traveling inside and outside $\mathrm{B} \& \mathrm{H}$, the authors used a probit model as a primarily methodological approach. The binary probit model is:

$$
e=\alpha+\beta_{1} \text { Age }+\beta_{2} \text { Education }+\beta_{3} \text { Household Income }
$$

where $e$ presents the logit (ln of the odds) of propensity to vis it tourist destinations in B\&H and propensity to travel abroad, respectively. Modelestimation was done by using STATA version 14.

\subsection{Research design}

The res earch is organized into three stages. The first stage introduces results of descriptive statisticalanalysis. The second stage refers to the probit model estimation. The empirical results of the research have been presented in the last phase.

\section{Results and discussion}

Within this chapter the authors will present the results of the empirical research.

The following table presents a short overview of the selected dependent variables.

Table 3: Overview of dependent variables

\begin{tabular}{|c|c|c|}
\hline Characteristic & Frequency & \% \\
\hline Travel habit in B \&H & \multicolumn{2}{|c|}{} \\
\hline Never & 168 & 26.60 \\
\hline One or more times & 464 & 73.40 \\
\hline Total & 632 & 100.00 \\
\hline Travel habit outside B\&H & \multicolumn{2}{|}{} \\
\hline Never & 272 & 43.00 \\
\hline One or more times & 360 & 57.00 \\
\hline Total & 632 & 100.00 \\
\hline
\end{tabular}

Source: Author's research

Based on the results presented in Table 3,26.6\% of res pondents, or 168 of them, stated that in the year in which the survey was conducted, they never visited any tourism-related places 
in $\mathrm{B} \& \mathrm{H}$ for the reas ons of vacation, recreation, leisure, entertainment, treatment, religion, etc. Significantly more respondents $73.4 \%$, or 464 of them, stated that they had visited a tourist destination in $\mathrm{B} \& \mathrm{H}$ at least once.

Out of 464 respondents who stated that in the year when the research was conducted, they visited a tourist destination in $\mathrm{B} \& \mathrm{H}$ one or more times, 292 of them, or $62.93 \%$, stated that they spent the night in those places (with friends, in a hotel, private accommodation, etc.).

When it comes to the habit of traveling outside $\mathrm{B} \& \mathrm{H}$, the majority of respondents, or $57 \%$ of them, stated that in the year when the survey was conducted, they visited tourist places in other countries one or more times.

A chi-square test of independence was performed to examine the difference between the propensity to travel in terms of gender, education, age, household income and marital status .

We found a statistically significant difference between the propensity to visit tourist destinations in $B \& H$ and age, $\chi^{2}(4, N=632)=17.429, p<0.05$, education, $\chi^{2}(3, N=$ $632)=33.736, p<0.001$, household income, $\chi^{2}(4, N=632)=29.638, p<0.001$.

In a similar way, a statistically significant difference has been confirmed between the propensity to travel abroad and age, $\chi^{2}(4, N=632)=25.670, p<0.001$, education, $\chi^{2}(3, N=632)=69.278, p<0.001$ and household income, $\chi^{2}(4, N=632)=$ $26.232, p<0.001$. These variables will be used in the rest of the analysis.

\section{Likelihood of visiting tourist destination}

To evaluate the impact of the age, education and household income on the (1) likelihood of visiting tourist destinations in B\&H (Model 1) and (2) likelihood of visiting tourist destinations outside $B \& H$ (Model 2), probit model was used.

The goodness-of-fit was evaluated using the following measures: Pearson chi-square statistics, Hosmer and Lemeshow goodness-of-fit test, classification tables and pseudo $\mathrm{R}^{2}$.

The results of the Pearson chi-square statistics verified the whole model (with all predictors included) as statistically significant $(\mathrm{p}=0.000)$ when it comes to Model 1 . Model 1 as a whole, matches substantially better than a model without predictors. The Hosmer and Lemeshow goodness-of-fit test $(\mathrm{p}=0.9027)$ als o verified this. According to the classification tables, Model 1 correctly clas sifies $75.00 \%$ of cases.

Furthermore, the results of the Pearson chi-square statistics verified the whole model (with all predictors included) as statistically significant $(\mathrm{p}=0.000)$ when it comes to Model 2 . This model as a whole, in other words, matches substantially better than a model without predictors. The Hosmer and Lemes how goodness-of-fit test $(p=0.0644)$ als o confirmed this . According to the classification tables, Model 2 correctly classifies $66.46 \%$ of cases.

As expected, both models $\left(\mathrm{R}^{2}=0.1032\right.$, for Model 1 and $\mathrm{R}^{2}=0.1159$ for Model2), produced a low value of pseudo $\mathrm{R}^{2}(0.1159)$.

Table 4 shows the results of the estimated models with marginal effects included. 
Table 4: The estimated models with the marginal effects

\begin{tabular}{|c|c|c|c|c|c|c|c|c|c|c|c|c|c|c|c|c|c|c|}
\hline \multirow[b]{2}{*}{ Independent variable } & \multicolumn{9}{|c|}{ Model 1} & \multicolumn{9}{|c|}{ Model 2} \\
\hline & $\boldsymbol{B}$ & S.E. & Sig. & MEMs & S.E. & Sig. & AMEs & S.E. & Sig. & $\boldsymbol{B}$ & S.E. & Sig. & MEMs & S.E. & Sig. & AMEs & S.E. & Sig. \\
\hline \multicolumn{19}{|l|}{ Age } \\
\hline Age category: $<25$ & 0.548 & 0.213 & 0.010 & 0.190 & 0.079 & 0.016 & 0.178 & 0.072 & 0.014 & 0.556 & 0.213 & 0.009 & 0.219 & 0.082 & 0.008 & 0.197 & 0.075 & 0.008 \\
\hline Age category: $26-35$ & 0.447 & 0.223 & 0.045 & 0.159 & 0.083 & 0.054 & 0.148 & 0.076 & 0.053 & 0.531 & 0.221 & 0.017 & 0.209 & 0.086 & 0.015 & 0.188 & 0.078 & 0.016 \\
\hline Age category: $36-45$ & 0.447 & 0.236 & 0.059 & 0.159 & 0.086 & 0.064 & 0.148 & 0.079 & 0.063 & 0.383 & 0.237 & 0.106 & 0.152 & 0.093 & 0.101 & 0.136 & 0.083 & 0.102 \\
\hline Age category: 46-55 & 0.794 & 0.259 & 0.002 & 0.255 & 0.084 & 0.002 & 0.243 & 0.079 & 0.002 & 0.220 & 0.248 & 0.376 & 0.087 & 0.097 & 0.373 & 0.078 & 0.087 & 0.374 \\
\hline \multicolumn{19}{|l|}{ Education } \\
\hline $\begin{array}{c}\text { Completed secondary } \\
\text { school }\end{array}$ & 0.065 & 0.210 & 0.758 & 0.023 & 0.076 & 0.760 & 0.022 & 0.073 & 0.760 & 0.332 & 0.210 & 0.114 & 0.129 & 0.079 & 0.102 & 0.124 & 0.076 & 0.104 \\
\hline University I cycle & 0.714 & 0.230 & 0.002 & 0.209 & 0.076 & 0.006 & 0.207 & 0.074 & 0.005 & 1.026 & 0.224 & 0.000 & 0.388 & 0.081 & 0.000 & 0.375 & 0.080 & 0.000 \\
\hline University II or III cycle & 0.992 & 0.443 & 0.025 & 0.259 & 0.092 & 0.005 & 0.259 & 0.093 & 0.005 & 1.659 & 0.434 & 0.000 & 0.546 & 0.099 & 0.000 & 0.533 & 0.100 & 0.000 \\
\hline \multicolumn{19}{|l|}{ Household income } \\
\hline 501-1,000 BAM & 0.174 & 0.178 & 0.328 & 0.062 & 0.064 & 0.334 & 0.059 & 0.061 & 0.333 & 0.148 & 0.176 & 0.400 & 0.059 & 0.070 & 0.400 & 0.053 & 0.063 & 0.400 \\
\hline 1,001-1,500 ВАM & 0.384 & 0.188 & 0.041 & 0.130 & 0.065 & 0.046 & 0.124 & 0.062 & 0.046 & 0.203 & 0.181 & 0.264 & 0.080 & 0.072 & 0.264 & 0.073 & 0.065 & 0.265 \\
\hline $1,501-2,000 \mathrm{BAM}$ & 0.192 & 0.201 & 0.340 & 0.068 & 0.072 & 0.341 & 0.065 & 0.068 & 0.342 & 0.231 & 0.198 & 0.244 & 0.092 & 0.078 & 0.242 & 0.083 & 0.071 & 0.245 \\
\hline$>2,000 \mathrm{BAM}$ & 1.403 & 0.318 & 0.000 & 0.314 & 0.059 & 0.000 & 0.314 & 0.058 & 0.000 & 0.875 & 0.232 & 0.000 & 0.313 & 0.077 & 0.000 & 0.289 & 0.072 & 0.000 \\
\hline _cons & 0.139 & 0.223 & 0.534 & - & - & - & - & - &.- & -1.049 & 0.267 & 0.000 & - & - & - & - & - &.- \\
\hline
\end{tabular}

Source: Author's research 
Speaking of age, the predicted likelihood that domicile population will visit at least one tourist destination in $\mathrm{B} \& \mathrm{H}$ is $19 \%$ greater for young individuals under 25 years of age, comparing to the individuals older than 55 . When it comes to propensity to travel abroad, the results indicate that age is an important factor. The predicted likelihood that resident will visit at least one tourist destination outside $\mathrm{B} \& \mathrm{H}$ is $21.9 \%$ greater for young individuals under 25 years of age, comparing to individuals older than 55. These findings are in accordance with the work of Handayani and Djamaluddin (2016) who found that age has positive effect on probability to go on vacation, and that of Ching-Fu and Wu (2009) who revealed that age has influence on propensity of seniors to travel overseas. Similar finding has been reported by Thrane et al. (2016) who showed that aging increases propensity for package tours as well as being first time visitor and by Toivonen (2004) who found the effect of interaction of age and regime on propensity was evident. Similarly, Seyidov and Adomaitiene (2016) found that the age of local Azerbaijani travellers affects their travel behaviour especially during their trip.

When it comes to education, the predicted likelihood that a resident will visit at least one tourist destination in $\mathrm{B} \& \mathrm{H}$ is $20.9 \%$ greater for an individual with cycle I university education and $25.9 \%$ greater for an individual with cycles II and III university education compared to those with elementary education. When it comes to education, the predicted likelihood that domicile population will vis it at least one tourist destination in $\mathrm{B} \& \mathrm{H}$ is $38.8 \%$ greater for an individual with cycle I university education, and 54.6\% greater for an individual with cycles II and III university education compared to those with elementary education. These findings are in accordance with the findings of Handayani and Djamalu ddin (2016) whose results showed that years of education have positive effect on probability of household to go on a vacation.

When it comes to hou sehold income, the predicted likelihood that a resident will vis it at least one tourist destination in $\mathrm{B} \& \mathrm{H}$ is $13.00 \%$ greater for an individual whose hous ehold income is 1,001-1,500 BAM, and 31.4\% greater for an individual whose household income is above 2,000 BAM, compared to those with household income of less than 500 BAM. Furthermore, the predicted likelihood that domicile population will visit at least one tourist destination in $\mathrm{B} \& \mathrm{H}$ is $31.3 \%$ greater for an individual whose household income is above 2,000 BAM to those with household income of less than 500BAM. These findings are in accordance with the work of Kožić et al. (2016) who found income to be the most important determinant of propensity to travel. Similar results have been reported by Handayani and Djamaluddin (2016) who showed that income has a positive effect on the probability of a household to go on a vacation. Furthermore, Ching-Fu and Wu(2009) have also revealed that income source and employment status are the major factors that have influence on the propensity of seniors to travel overs eas. Similarly, Seyidov and Adomaitienè(2016) found that monthly income of local Azerbaijani travellers affects their travel behaviour especially during their trip.

\section{Conclusion}

Propensity to travel is definitely one of the fundamental concepts of tourism research. However, it is probably true to say that so far little attention has been paid to residents' propensity to travel to local tourist destinations. Based on this research gap, the purpose of this paper was to provide some insights into socio-demographic determinants of the residents' propensity to travel. The research findings have revealed that age, education and hous ehold income characteris tics may be considered as antecedents of the travel propensity of residents.

Propensity to travel is a multidimensional concept. Therefore, our research may have some potential limitations. The first one refers to the problem of omitted variables. In addition to 
socio-demographic variables, there are many other variables that influence propensity to travel. The most important individual characteristics of a person are: socio-demographic characteristics, experience, satisfaction, pleasure, novelty, vacation, recreation, life style, prestige, purchasing power, etc., while the most important social factors are: culture, values and norms, social attitude towards free time, work and life environment, affiliation with social or religious group, standard of living, etc. Based on this, we can recommend that future research encompass those factors.

The study's other drawback is that the available data is cross-sectional rather than longitudinal. One of possible limitations is non-probabilistic type of sample. In addition, data collection is conducted before the beginning of the Covid-19 pandemic.

Besides viewing propensity to travel in a way that is followed in this paper, it can be observed frommultiple aspects the most important of which are: the number of tourist trips during a year, number of domestic tourist trips, number of tourist trips abroad, leng th of stay, number of people with whom someone travels, social relationship with those persons (hous ehold members, relatives, friends), etc. We can differentiate between net and gross propensity to travel. Also, there is frequency of trips (Šuran, 2016). Net propensity to travel repres ents percentage of population that goes on at least one trip d uring specific time period, while gros s propensity to travel represents total number of tourist trips viewed as percent relative to a whole population. Frequency of trips is the ratio between gross and net propensity to travel. Another recommendation for future research concerns these notions.

Having in mind the impact that the Covid-19 pandemic has on the sector of tourism worldwide, and based on the results of this res earch, policymakers' efforts should be directed to promoting local tourist destinations and to enhancing travel and tourism literacy of residents.

\section{Conflict of interest}

The authors declare no conflict of interest.

\section{References}

1. Bianchi, C., \& Milberg, S. (2017). Investigating non-visitors' intentions to travel to a long-haul holiday destination. Journal of Vacation Marketing, 23(4), 339-354. https ://doi.org/10.1177/1356766716653646

2. Ching-Fu, C., \& Wub, C. (2009). How motivations, constraints, and demographic factors predict seniors' overseas travel propensity. Asia Pacific Management Review, 14(3), 301-312.

3. Choi, K. H., Kim, M., \& Leopkey, B. (2019). Prospective tourists' risk perceptions and intentions to travel to a mega-s porting event host country with apparent risk. Journal of Sport \& Tourism, 23(2-3), 97-114. https://doi.org/10.1080/14775085.2020.1715826

4. Dogru, T. (2016). Chinese propensity to purchase a vacation: The role of financial behavior and confidence in economy. Tourism: An International Interdisciplinary Journal, 64(2), 149-158.

5. Gurbaskan Akyuz, B. (2019). Factors that influence local food consumption motivation and its effects on travel intentions. Anatolia, 30(3), 358-367. https://doi.org/10.1080/13032917.2019.1595072

6. Handayani, D., \& Djamaluddin, S. (2016). The propensity of household to go on vacation, Indonesia. International Conference on Tourism, Gastronomy, and Tourist Destination (ICTGTD 2016), Atlantis Press. https ://doi.org/10.2991/ictgtd-16.2017.38 
7. Hur, Y., \& Adler, H. (2013). An exploratory study of the propensity for South Koreans to take cruises: Investigating Koreans' perceptions of cruise ship travel. International Journal of Tourism Research, 15(2), 171-183. https://doi.org/10.1002/jtr.1862

8. Kožić, I., Mikulić, J., \& Krešić, D. (2016). Propensity to travel: What the macro-data are telling us? In Á., Matias, P., Nijkamp \& J., Romão (Eds.), Impact Assessment in Tourism Economics (pp. 9-22). Cham: Springer International Publishing. https://doi.org/10.1007/978-3-319-14920-2_2

9. Letheren, K., Martin, B. A., \& Jin, H. S. (2017). Effects of personification and anthropomorphic tendency on destination attitude and travel intentions. Tourism Management, 62, 65-75. https://doi.org/10.1016/j.tourman.2017.03.020

10. Seyidov, J. \& Adomaitienè, R. (2016). Factors influencing local tourists' decisionmaking on choosing a destination: A case of Azerbaijan. Ekonomika, 95(3), 112-127.

11. Šuran, F. (2016). Slobodno vrijeme, putovanje i turizam: Sociološki pristup [Leisure, travel and tourism: A sociological approach]. Buje: Happy.

12. Thrane, C., Menezes, A. G. D., \& Uzagalieva, A. (2016). A multivariate logit for propensity to choose package tourover independent travel. CEEAplA-A-Working Paper Series, 1-25.

13. Toivonen, T. (2004). Changes in the propensity to take holiday trips abroad in EU countries between 1985 and 1997. Tourism Economics, 10(4), 403-417. https://doi.org/10.5367/0000000042430935 